\title{
From the 'Small but Smart State' to the 'Small and Entrepreneurial State': Introducing a Framework for Effective Small State Strategies within the EU and Beyond ${ }^{1}$
}

\author{
Revecca Pedi \\ Department of International and European Studies, \\ University of Macedonia \\ Egnatias 156 \\ Thessaloniki 54636, Greece \\ E-mail: rpedi@uom.gr \\ Katerina Sarri \\ Department of Balkan, Slavic and Oriental Studies, \\ University of Macedonia \\ Egnatias 156, \\ Thessaloniki 54636, Greece \\ E-mail: ksarri@uom.edu.gr
}

Abstract: As the current international system is leaning towards multipolarity, small states face the danger of their influence being diminished and their interests being ignored. Small states in Europe and within the European Union might find themselves in such a predicament. In order to overcome it, they are in need of effective strategies. Literature on the international relations of small states suggests that, despite their limitations, small states are able to pursue their goals and succeed in the international system. Small state studies employ the 'small but smart state' concept for a small state that can maximize its influence. Despite being widely used, the latter lacks analytical value and remains a cliché. The objective of this article is to pin down the 'small but smart'state strategy and based on that to provide a comprehensive framework for the analysis and the design of effective small state strategies. We suggest that the 'small but smart' state strategy shares many elements with the entrepreneurial

1 An earlier version of this study was presented at the 12th EISA Pan-European Conference on International Relations, Prague, Czech Republic, 12-15 September 2018. 
action, as the latter is extended from its business origins to include a specific strategy. We draw on the field of entrepreneurship to explore the ways it can enhance our understanding of the international relations of small states and we introduce a framework for the 'small and entrepreneurial state' strategy. The notion of the 'small and entrepreneurial state' adds more depth and rigor into our small state analyses as well as reinvigorates a fragmented and repetitive literature. Last but not least, our 'small and entrepreneurial state' approach can be of use for both small state scholars and policy makers.

Keywords: entrepreneurial state, entrepreneurship in international relations, small but smart state, small states

\section{Introduction}

One of the mantras in the international relations of small states is that the latter can 'punch above their weight', increase their influence in the international system, and even bring about changes, despite their limitations (see Björkdahl, 2008; Ingebritsen, 2002; Krasner, 1981; Smed \& Wivel, 2016). Although such a claim is important for every era, it is of significant value for the current international system that is leaning towards multipolarity and therefore involves the danger of the influence of the small states being diminished and of their interests being ignored. Small states in Europe and within the European Union (EU) might find themselves in such a predicament. In principle, all Member States participate in the EU on an equal footing. Yet, asymmetry of power matters, as smaller Member States dispose less resources and have to employ effective strategies in order to 'punch above their weight'.

However, our understanding of the mechanics that enable small states to serve their interests, introduce innovative policies, new norms and institutions, to advance small-scale changes within the EU, in other international organizations, in interstate relations, at a regional level and in the system, is incomplete. To conceptualize the accomplished small state, scholars have employed the term 'small but smart state'. The 'small but smart state' concept has become a catchphrase among small state scholars, international institutions, and politicians (Arter, 2000; Joenniemmi, 1998; Grøn \& Wivel, 2011; Kouskouvelis, 2015; Milta, 2016; Pastore, 2013; Prasad, 2009; The World Bank, 2018; Wivel, 2010). Yet, it remains obscure as 'smart' cannot but be generic; it is used in 
many different contexts, for example 'smart specialization' (Prause, 2014) or 'smart contracting' (Solarte-Vásquez \& Katrin Nyman-Metcalf, 2017); it means different things to different people and therefore lacks focus and analytical value. As a result, the 'small but smart' state literature grew in a haphazard way and remains fragmented. Therefore, we need to get a better understanding and thorough analysis of the so-called 'small but smart state' strategy.

The objective of this paper is to pin down the 'small but smart' state strategy and provide a comprehensive framework for analysing and designing effective small state strategies. To this aim. we explore 'smartness' and 'smallness' and we look for insights that enhance our understanding of strategies of problem solving, innovation and accomplishment. We draw on research conducted in the field of entrepreneurship and we argue that the 'small but smart state' behaviour shares many elements with the entrepreneurial action, as the latter is extended from its business origins to include a specific strategy. Thus, we introduce a framework for the analysis of the 'small and entrepreneurial state' strategy.

In order to pin down the 'small but smart state' strategy and build the 'small and entrepreneurial state' strategy framework, we employed two bodies of literature. We first reviewed scholarship on the international relations of small states and identified the elements of the 'small but smart state' strategy. Then, in order to systematize those elements we looked for insights in the field of entrepreneurship and especially on works that extend entrepreneurship beyond its business origins. We chose to employ an interdisciplinary approach and draw on the field of entrepreneurship for four different reasons. First, we have been alarmed by small state scholars who had used terms from the entrepreneurship vocabulary before (see Arter, 2000; Browning, 2006; Rickli, 2008; Wivel, 2010). Second, Miles (2015, p. 134) argues that "FPA [Foreign Policy Analysis] and political entrepreneurship scholars have, in many ways, been addressing similar research puzzles $[\ldots]$ associated with policy change and continuity, but have simply been using different language (or keys) to open them". Third, scholars from the field of entrepreneurship too have encouraged the exploration of the relevance of their findings to other fields of study (Lumpkin, 2011; Sarasvathy \& Venkataraman, 2011). Last but not least, there is a tradition in the international relations discipline to draw on economics for inspiration (see Waltz, 1979) and we adhere to it. In this sense, we follow Ripsman, Taliaferro and Lobell (2016, p. 130) who suggest that when the international relations discipline lacks a theory for understanding a phenomenon, it is possible for the researchers to "draw out the logical implications for other contexts and suggest hypotheses regarding the issue in question for empirical testing." 
Therefore, this article contributes to the debate on the international relations of small states a new perspective on efficient small state strategies. It enhances our understanding of the 'small but smart state' strategy and introduces a systematic framework for analysing old and new empirics and designing effective small state strategies. Moreover, it expands the use of entrepreneurship insights in international relations and encourages further interdisciplinary research.

\section{Smartness and smallness}

Smartness in international relations literature is usually associated with Nye's 'smart power' concept (2008), which involves a mixture of hard and soft power instruments and means that should be used appropriately with regard to the respective context (see Cross, 2011). However, small state scholars have taken a different approach. Joenniemi (1998), who introduced the smartness aspect in the field, connects smartness with small states' ability to adapt, be influential and not have any of the liabilities that accompany the great powers in the system. His account of smartness is brief and mainly suggestive. Later, most of the small state studies that employ the smartness perspective make an implicit or explicit association between smartness and influence. Most of them focus on the steps and the preconditions of a strategy that enables a small state to maximize its influence (Arter, 2000; Bueger \& Wivel, 2018; Grøn \& Wivel, 2011; Kouskouvelis, 2015; Wivel, 2010). Initially, studies of the 'small but smart' state focused on the EU (Arter, 2000; Grøn \& Wivel, 2011; Milta, 2016; Pastore, 2013; Wivel, 2010). Kouskouvelis (2015) put smartness in a broader perspective of bilateral and regional relations and associated it with smart leadership. Also, Tarp and Hansen (2013) refer to the smart ways in which small states act within the United Nations. In addition, Bueger and Wivel (2018) show how Seychelles, a micro-state, has acted as a 'small but smart' state on the international stage and managed to extend its influence. Prasad (2009) correlates smartness with the ways that small states find to navigate an adverse international economic environment and increase their wealth. Thus, the meaning of the 'small but smart' state remains fluid and dependent upon the context of the analysis. Hence, its usefulness is diminished and there is a need for further conceptualization of the efficient small state strategy.

Apart from the term 'small but smart' state, scholars have also referred to small states' wisdom (Fox, 1959), intelligence (Katzenstein, 1985) and cleverness (Platias, 1986). They use those terms in order to conceptualize the behaviour of 
the small state that manages to serve its interests, despite its limitations and in a context where great powers prevail; the small state that manages to maximize its influence against all odds. In this sense, 'smartness' is directly associated with smallness; it refers to a small state's efforts to overcome the implications of having limited resources. Under this perspective, 'smartness' does not refer simply to influence maximization. It encompasses both means and ends and it takes into consideration the given circumstances; smartness refers equally to the ultimate goal and the steps that a small state takes to reach it, given its limited resources and its place in the hierarchy of the international system, its lack of clout. Thus, 'smartness' refers to an effective use of means to the attainment of a specific end, which is none other than the maximization of influence. Of course, influence is not an abstract end in itself; 'small but smart' states aspire to enhance their position in the system and safeguard their interests.

Against this background, one important aspect of the 'small but smart' state strategy is that it takes into account the existing power configuration and the implications of power disparity between great powers and small powers. For a 'small but smart' state smallness matters; it is a predicament, but not an insuperable obstacle. Based on the fact that small powers have fewer resources and less influence than great powers; the 'small but smart' state devises strategies to overcome its limitations. In this sense 'small but smart' states are agile and proactive states that take initiatives within the context of alliances, international organizations, the EU and in their interstate relations, in order to maximize their influence. 'Small but smart' states even exploit their predicament (Grøn \& Wivel, 2011). Due to their smallness, they do not provoke 'security dilemmas' to more powerful actors, and they are able to undertake initiatives and roles that suit their power resources and are of different nature and scale in comparison with those that great powers hold; yet they still manage to pursue and secure their interests (see Ingebritsen, 2002). A series of studies reconfirms that creativity, flexibility and expertise play a great role in this context (e.g., Schmidl, 2001; Cooper \& Shaw, 2009; Rickli, 2008; Grøn \& Wivel, 2011; Panke 2012a; 2012b). In addition, when small states manage to "punch above their weight' they usually take advantage of favourable circumstances, whether systemic, such as great powers rivalry, institutional, such as holding the presidency of an organization or that of the EU Council; or derived from a state's geography, discovery of natural resources, competent leadership (see Grøn \& Wivel, 2011; Kouskouvelis, 2015).

Moreover, institutional environment permitting, small states create new space for their action. The case of the corporation of the Petersberg Tasks in the context of the then European Security and Defence Policy, promoted by Sweden and 
Finland, both of which have later assumed important roles in the implementation of the EU's Security and Defence Policy, constitutes such an example (Björkdahl, 2008; Jacobsen, 2009). For such initiatives to succeed, small states should be adaptable, proactive, innovative and persistent (Arter, 2000; Björkdahl, 2008; Jacobsen, 2009; Ricki, 2008; Tiilikainen, 2006; Thorhallsson, 2012). To this background, small states usually aspire to bring about low-scale changes that serve their interests and/or are related to their expertise. Additionally, small states that succeed in maximizing their influence cannot afford to act alone. 'Small but smart states' capitalize on the resources of other actors, great powers and/or other small states, institutions, and NGOs (Rickli, 2008; Panke, 2012a; 2012b; Nasra, 2011; Thorhallsson, 2012; Súilleabháin, 2014). Moreover, in order to evolve and succeed, a small state's initiative or contribution should add some value, make a difference in the regional or the international system and benefit other partners too (Arter, 2000; Wivel, 2010). The actions of the 'small but smart' states are, or at least appear, as beneficial not only to them but also to other actors and even the system as a whole.

To sum up, a 'small but smart state' is a state that makes an effective use of its limited resources, harnesses favourable circumstances, creates space for action, cooperates with others in order to serve its interests, brings about a change or changes and acts in a way that is beneficial for itself and for others. Creativity, innovativeness, flexibility, adaptability, proactiveness, expertise and a good reputation are the necessary qualities. Against this background, a state can 'punch above its weight' through acting as a mediator, an honest broker, a policy or norm entrepreneur, an expert (Pedi, 2016). Hence, the vague 'small but smart state' concept obscures more than it reveals and therefore we need a concept with more analytical value to help us theorize about effective small state strategies.

\section{Entrepreneurship: from an established academic field to an academic trend}

Entrepreneurship as a field of study has gained considerable legitimacy during the last decades (Lumpkin, 2011). It is usually associated with the creation of a new business organization or the growth of an existing one. Yet, prominent figures in the field of entrepreneurship field have suggested that we should treat it as something more than a "sub-discipline of economics or management" (Sarasvathy \& Venkataraman, 2011, p. 114) and seek to find how it informs 
life (Lumpkin, 2011). For Sarasvathy and Venkataraman (2011, p. 125), there is a "distinct method of human problem solving that we can categorize as entrepreneurial". According to them entrepreneurship as a

phenomenon may hide a generalized method capable of changing the way we live, work and play, and transforming the courses of the careers we build, the shapes of the communities we live in, and the evolution of the socio-political and economic systems we are part of. (Sarasvathy \& Venkataraman, 2011, p. 115)

Lumpkin argues that a critical question that entrepreneurship scholars have to ask is

how entrepreneurial knowledge can contribute to understanding goal accomplishment and human achievement generally [...]. What is the role of opportunity identification and creation, innovativeness and competitiveness, risk-taking, and autonomy in human accomplishment, in the purposeful enactment of all types of personal and organizational goals? (Lumpkin, 2011, p. 7)

In other words, he asks "what the impact of acting entrepreneurially has on outcomes outside of business, or on the human condition more generally."

However, different scholars conceptualize the entrepreneur in different ways (Sarri et al., 2012). The main constitutive elements of entrepreneurship that we usually come across in literature are: scarce resources, opportunity, creativity, innovation, risk-taking, uncertainty, change effectuation and value creation (Sarri et al., 2012). Moreover, scholars have also underlined the role that autonomy, proactiveness, responsiveness and adaptiveness to challenges posed by the environment and competition, among others, play in the entrepreneurial orientation (Lumpkin \& Dess, 1996). In this context, opportunities "understood as positive and favourable circumstances leading to entrepreneurial action" are central and "arise from changes in the environment in which an individual operates" (George et al., 2014, p. 1). Eckhardt and Shane (2003, p. 336) define "entrepreneurial opportunities as situations in which new goods, services, raw materials, markets and organizing methods can be introduced through the formation of new means, ends, or means-ends relationships." Furthermore, they suggest that what distinguishes entrepreneurial decisions from other decisions that generate profit is that "entrepreneurial decisions are creative decisions", as the ends and the means are not given; "the entrepreneur constructs the means, the ends, or both" (Eckhardt \& Shane, 2003, p. 336). 
The use of entrepreneurship in other social sciences has proliferated after the 2000s and mainly in the American academic world (Pozen, 2008). Indeed, concepts like those of the social entrepreneur (Martin \& Osberg, 2007), the norm entrepreneur (Finnemore \& Sikkink, 1998), the political entrepreneur (Petridou, Aflaki \& Miles, 2015), and the moral entrepreneur (Posner, 1999) have become popular among scholars in disciplines such as sociology, political science and law. Although all the above concepts are based on the notion of the entrepreneur, they capture it in different ways that are not always consonant with each other. In addition, they do not always directly correspond to the mainstream entrepreneurship literature. However, what can be conceived as the common denominator of the various efforts that employ the concept of the entrepreneur is an emphasis on opportunity, creativity, innovation, accomplishment, change and value creation.

\section{Entrepreneurship in politics and international relations}

For Petridou, Aflaki and Miles (2015), entrepreneurship in politics is the "purposive political action of getting hold of opportunities for political profit". They have managed to capture the essence of the different approaches to entrepreneurship in their definition of political entrepreneurship. According to them, "a political entrepreneur is a special kind of actor, embedded in the sociopolitical fabric, who is alert to the emergence of opportunities and acts upon them; he or she amasses coalitions for the purpose of effecting change in a substantive policy sector, political rules or in the provision of public goods." (Petridou, Aflaki \& Miles, 2015, pp. 1-2) They associate "entrepreneurial action in the polis, much like in market entrepreneurship" with creativity, innovation and profit, which in the context of the 'polis' is political profit (Petridou, Aflaki \& Miles, 2015, pp. 1-2).

Although economics has had a great impact on shaping thinking in the international relations discipline (see Waltz, 1979), the use of entrepreneurship insights and of the concept of the entrepreneur is limited and sporadic. There are only a few studies that engage with entrepreneurship, beyond the concept of the "norm entrepreneur" (Finnemore \& Sikkink, 1998; Ingebritsen, 2002); however, each of them holds a different perspective and scope (Frohlich \& Oppenheimer, 1972; Checkel, 1993; Moravcsik, 1999; Carter \& Scott, 2010; Blavoukos \& Bourantonis, 2012; David, 2015; Miles, 2015). For most of them, entrepreneurs are individual leaders or practitioners who follow innovative approaches, transform public beliefs inside or outside their countries, break 
with past behaviour or perceptions, and provide public goods. Thus, they investigate the ways that political entrepreneurs at the domestic level, or within a supranational institution, influence policy change in the foreign policy domain. These approaches make an effective use of the concept of the political entrepreneur, in order to understand change in the foreign policy of a state or changes within a supranational institution. Our perspective is new in that it focuses on a different level of analysis. Observing that when studies engage with entrepreneurship, it is rarely with the aim of analysing choices at the state level, we look at this level of analysis and we seek to find what is the explanatory power of entrepreneurship insights for enhancing our understanding of the 'small but smart' state strategy.

\section{Towards an entrepreneurial strategy framework}

Our approach is based on the analogy between the international system and the market that Waltz introduced in 1979. We assume that if great powers act as big firms, then small states act as small firms - namely, more entrepreneurially. We agree with Miles (2015, p. 134) that there are "common among FPA and political entrepreneurship puzzles". Miles does not name them explicitly. In our understanding these are: the issue of survival, the fact that both states and entrepreneurs act as maximizers, both are concerned with cooperation and competition, with absolute and relative gains, both face structural constraints and they have to handle the difficulties of uncertainty and anarchy, of the lack of information and, in many cases, of the existence of scarce resources.

Moreover, the language of entrepreneurship is used extensively by small state scholars. Arter (2000, p. 691) suggests that small states are smart in the "sense of being enterprizing" and that they are also marketing their ideas. Wivel (2010) emphasizes the importance of an environment that encourages innovation and of a strategy that adds value, as preconditions for success. Also, Browning (2006, p. 679) argues that what matters nowadays is not so much the relative size of a state but "whether a state is innovative and active". In addition, Cooper and Shaw $(2009$, p. 2) note that "[w] hat small states lack in structural clout they can make up through creative agency". Furthermore, Rickli (2008) suggests that small states wishing to play a role in the post-Cold War security architecture, should exploit relevant niches. These examples show that small state scholars have captured the essence of the entrepreneurial action; yet they have lacked a framework that would allow them to describe, explain and test it in a systematic way. 
In this context, bearing in mind the elements of the 'small but smart' state strategy analysed above relying on a synthesis of insights from both market and political entrepreneurship, as discussed previously, we suggest that there is 'a small and entrepreneurial' state strategy and we provide a framework for a more systematic analysis (see Fig. 1). According to our framework:

- States undertake entrepreneurial action as a problem-solving strategy in order to respond and/or adapt to challenges and opportunities posed by their environment and fight off competition from other states.

- Alertness to opportunities and change effectuation lie at the core of entrepreneurial action. In this context, opportunity-"positive and favourable circumstances leading to entrepreneurial action" (George et al., 2014, p. 1) - can arise from changes (material or ideational) in the international or regional system. It can be institutional, in the context of a supranational organization; it can relate to geography or a specific expertise that a state has; it may come from the potential exploitation of natural resources and even from changes in a state's leadership.

- As states get hold of opportunities in order to increase their profit - that is maximization of influence - they innovate by introducing new ideas, norms, policies, partnerships, and institutions. As they introduce new means, or new ends, or new means-ends relationships their decisions are entrepreneurial decisions (George et al., 2014).

- In this way, small states bring about change at a regional or international level and generate value, i.e. prosperity, security, stability for themselves and others. Thus, entrepreneurial action by a small state, transforms an opportunity into a change.

- The entrepreneurial state is a state that withstands uncertainty, takes risks, is proactive, creative and responsive. It recognizes that the international system is a self-help system (Waltz, 1979) and therefore, as also entrepreneurs do, it holds a developed 'internal locus of control', which means that it accepts that it is responsible for its own fate.

- Forming coalitions and capitalizing upon the resources of others is also an indispensable part of an entrepreneurial state strategy.

- States, depending on their resources, can act entrepreneurially at an international or regional level, within institutions, such as the EU or the $\mathrm{UN}$, and in their interstate relations.

In contrast to the 'small but smart state' approach which is generic and vague, the 'small and entrepreneurial state' is associated with entrepreneurial action which is specific. It has to do with limited resources, alertness to opportunity, proactiveness, creativity, innovation, change, and value creation in a competitive 
environment. It allows us to systematize our knowledge about the small state that makes an effective use of its limited resources, maximizes its influence and generates value in the system. In addition, it invites further interdisciplinary research on the nature of opportunities, the processes of entrepreneurial decision, change effectuation and value creation in the international system - aspects of international relations that have been hardly investigated in the discipline.

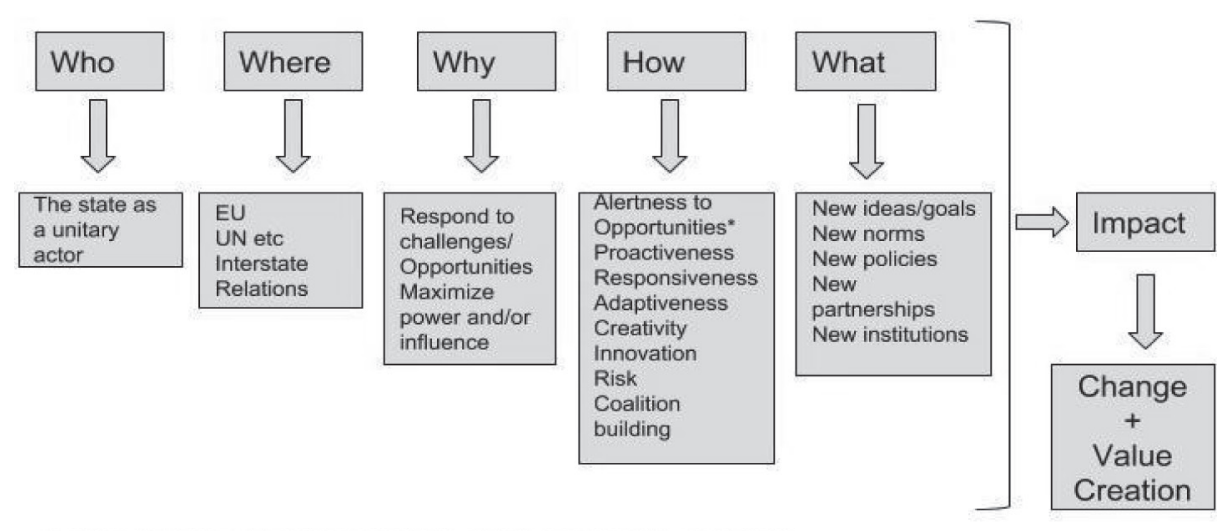

*systemic, institutional, geography, natural resources, expertise, leadership

Figure 1. A small and entrepreneurial state strategy framework

Such a framework can shed some new light on a series of old empirics; to name but a few cases: Estonia's expertise in responding to cyberattacks and its contribution to both the EU and NATO in this area (Crandall, 2014; Crandall \& Allan, 2015); Denmark's action in the area of counter-piracy (Smed \& Wivel, 2016); Cyprus' status-seeking strategy in the Eastern Mediterranean (Pedi \& Kouskouvelis, 2019). Equally, it can be useful for analysing new cases and advancing new proposals. In addition, it can be helpful in enhancing policy makers' understanding of effective strategies and in devising new ones.

\section{Conclusion}

This article pinned down the 'small but smart' state strategy and introduced a framework that could help both researchers and practitioners to make sense of effective small states' strategies. We suggested that smartness refers to the efficient use of a small state's limited resources in order to serve its interests and maximize its influence and we identified the elements of a 'small but smart state' strategy. These elements, we argued, can be integrated into a comprehensive 
framework with the help of insights from the field of entrepreneurship. Thus, we associate a small state effective strategy with entrepreneurial action. Small states that follow an entrepreneurial strategy are aware of their limitations and therefore they are proactive and creative, they harness opportunities and innovate. As a result, they are able to effect changes to their advantage and generate value in the system.

Thus, entrepreneurial knowledge (see Lumpkin, 2011) contributes to a more comprehensive and thorough understanding of the 'small but smart' state strategy. The development of the entrepreneurial state strategy framework in this context can be useful to both researchers of the accomplishments of small states and policy makers. By pinning down the 'small but smart' state strategy, we make it available to even more small states that wish to maximize their influence and introduce changes to their advantage. Clearly, it is not the privilege of some enlightened states, but the outcome of employing a certain problem-solving method, namely, entrepreneurial action. Moreover, the integration of insights from the research field of entrepreneurship into the discipline of international relations provides us with new possibilities for research on opportunity, change, value creation and co-opetition-the combination of cooperation and competition-which have been hardly explored before in the International Relations discipline.

Revecca Pedi is an assistant professor in the Department of International and European Studies at the University of Macedonia. Her research is focused on the international relations of small states and she has published chapters in edited volumes, articles in academic journals, as well as op-eds on this topic. She has studied at the University of Macedonia, University of Sheffield and University of Cambridge.

Katerina Sarri, professor of management, director of the Entrepreneurship Lab at the University of Macedonia, coordinator/tutor for Entrepreneurship \& Innovation at the Hellenic Open University, national coordinator for the Global University Entrepreneurial Spirit Students' Survey (GUESSS), has extensive teaching, consulting, assessing and research experience. She has authored/co-authored five books in management and entrepreneurship. 


\section{References}

Arter, D. (2000), 'Small state influence within the EU: the case of Finland's 'Northern Dimension Initiative', JCMS: Journal of Common Market Studies, vol. 38, no. 5, pp. 677-697. https://doi.org/10.1111/1468-5965.00260

Björkdahl, A. (2008), 'Norm advocacy: a small state strategy to influence the EU,' Journal of European Public Policy, vol. 15, no. 1, pp. 135-154. https://doi.org/10.1080/13501760701702272

Blavoukos, S. \& Bourantonis, D. (2012), 'Policy entrepreneurs and foreign policy change: the Greek-Turkish rapprochement in the 1990s,' Government and Opposition, vol. 47, no. 4, pp. 597-617. https://doi.org/10.1111/j.1477-7053.2012.01376.x

Browning, C. (2006), 'Small, smart and salient? Rethinking identity in the small states literature,' Cambridge Review of International Affairs, vol. 19, no. 4, pp. 669-684. https://doi.org/10.1080/09557570601003536

Bueger, C. \& Wivel, A. (2018), 'How do small island states maximize influence? Creole diplomacy and the smart state foreign policy of the Seychelles,' Journal of the Indian Ocean Region, vol. 14, no. 2, pp. 170-188. https//doi.org/10.1080/19480881.2018.1471122

Carter, R. G. \& Scott, J. M. (2010), 'Understanding congressional foreign policy innovators: mapping entrepreneurs and their strategies,' The Social Science Journal, vol. 47, no. 2, pp. 418-438. https://doi.org/10.1016/j.soscij.2009.12.003

Checkel, J. (1993), 'Ideas, institutions, and the Gorbachev foreign policy revolution,' World Politics, vol. 45, no. 02, pp. 271-300. https://doi.org/10.2307/2950660

Cooper,A.\& Shaw, T.(2009), Diplomacies of Small States: Resilienceversus Vulnerability, New York: Palgrave MacMillan. https://doi.org/10.1057/9780230246911

Crandall, M. (2014), 'Soft security threats and small states: the case of Estonia,' Defence Studies, vol. 14, no. 1, pp. 30-55.

https://doi.org/10.1080/14702436.2014.890334

Crandall, M. \& C. Allan (2015), 'Small states and big ideas: Estonia's battle for cybersecurity norms,' Contemporary Security Policy, vol. 36, no. 2, pp. 346-368. https://doi.org/10.1080/13523260.2015.1061765

Cross, M. D. (2011), 'Europe, a smart power?' International Politics, vol. 48, no. 6, pp. 691-706. https://doi.org/10.1057/ip.2011.28

David, C. P. (2015), 'How do entrepreneurs make national security policy? A case study of the G. W. Bush Administration,' in I. Aflaki, E. Petridou \& L. Miles (eds.) Entrepreneurship in the Polis: Understanding Political Entrepreneurship, London: Ashgate Publishing, Ltd., pp. 151-170. 
Eckhardt, J. T. \& Shane, S. A. (2003), 'Opportunities and entrepreneurship,' Journal of Management, vol. 29, no. 3, pp. 333-349. https://doi.org/10.1177/014920630302900304

Finnemore, M. \& Sikkink, K. (1998), 'International norm dynamics and political change,' International Organization, vol. 52, no. 04, pp. 887-917. https://doi.org/10.1162/002081898550789

Fox, A. (1959), The Power of Small States: Diplomacy in WWII, Chicago: Chicago University Press.

Frohlich, N. \& Oppenheimer, J. A. (1972), 'Entrepreneurial politics and foreign policy,' World Politics, vol. 24, no. S1, pp. 151-178. https://doi.org/10.2307/2010562

George, N. M.; Parida, V.; Lahti, T. \& Wincent, J. (2016), 'A systematic literature review of entrepreneurial opportunity recognition: insights on influencing factors,' International Entrepreneurship and Management Journal, vol. 12, no. 2, pp. 309-350. https://doi.org/10.1007/s11365-014-0347-y

Grøn, C. H. \& Wivel, A. (2011), 'Maximizing influence in the European Union after the Lisbon Treaty: from small state policy to smart state strategy,' Journal of European Integration, vol. 33, no. 5, pp. 523-539. https://doi.org/10.1080/07036337.2010.546846

Ingebritsen, C. (2002), 'Norm entrepreneurs: Scandinavia's role in world politics,' Cooperation and Conflict, vol. 37, no. 1, pp. 11-23. https://doi.org/10.1177/0010836702037001689

Jakobsen, P. (2009), 'Small states, big influence: the overlooked Nordic influence on the civilian ESDP,' JCMS: Journal of Common Market Studies, vol. 47, no. 1, pp. 81-102. https://doi.org/10.1111/j.1468-5965.2008.01833.x

Joenniemi, P. (1998), 'From small to smart: reflections on the concept of small states,' Irish Studies in International Affairs, vol. 9, pp. 61-62.

Katzenstein, P. J. (1985), Small States in World Markets: Industrial Policy in Europe, Ithaca, NY: Cornell University Press.

Kouskouvelis, I. (2015), 'Smart leadership in a small state: the case of Cyprus,' in A. Tziampiris \& S. Litsas (eds.) The Eastern Mediterranean in Transition: Multipolarity, Politics and Power, Abingdon: Routledge, pp. 93-117.

Krasner, S. D. (1981), 'Transforming international regimes,' International Studies Quarterly, vol. 25, no. 1, pp. 119-148. https://doi.org/10.2307/2600213

Lumpkin, G. T. (2011), 'From legitimacy to impact: moving the field forward by asking how entrepreneurship informs life,' Strategic Entrepreneurship Journal, vol. 5, no. 1, pp. 3-9. https://doi.org/10.1002/sej.104

Lumpkin, G. T. \& Dess, G. G. (1996), 'Clarifying the entrepreneurial orientation construct and linking it to performance,' Academy of Management Review, vol. 21, no. 1, pp. 135-172. https://doi.org/10.5465/amr.1996.9602161568 
Martin, R. L. \& Osberg, S. (2007), 'Social entrepreneurship: the case for definition,' Stanford Social Innovation Review, vol. 5, no. 2, pp. 28-39.

Miles, L. (2015), 'Political Entrepreneurship as painful choices: an examination of Swedish (post)-neutrality security policy,' in I. Aflaki, E. Petridou \& L. Miles (eds.) Entrepreneurship in the Polis: Understanding Political Entrepreneurship, London: Ashgate Publishing, Ltd., pp. 133-150.

Milta, M. (2015), 'Lithuania's foreign policy under the Eastern Partnership Programme in 2009-2014: from small state policy to smart state strategy,' Lithuanian Foreign Policy Review, vol. 33, no. 1, pp. 27-47. https://doi.org/10.1515/lfpr-2016-0008

Moravcsik, A. (1999), 'A new statecraft? Supranational entrepreneurs and international cooperation,' International Organization, vol. 53, no. 02, pp. 267-306.

https://doi.org/10.1162/002081899550887

Nasra, S. (2011), 'Governance in EU foreign policy: exploring small state influence,' Journal of European Public Policy, vol. 18, no. 2, pp. 164-180. https://doi.org/10.1080/13501763.2011.544490

Nye, Jr., J. S. (2008), The Powers to Lead, Oxford: Oxford University Press.

Panke, D. (2012a), 'Dwarfs in international negotiations: how small states make their voices heard,' Cambridge Review of International Affairs, vol. 15, no. 3, pp. 313-328. https://doi.org/10.1080/09557571.2012.710590

Panke, D. (2012b), 'Small states in multilateral negotiations. What have we learned?' Cambridge Review of International Affairs, vol. 15, no. 3, pp. 387-398. https://doi.org/10.1080/09557571.2012.710589

Pastore, G. (2013), 'Small new Member States in the EU foreign policy: toward 'Small State Smart Strategy'?' Baltic Journal of Political Science, vol. 3, pp. 67-84. https://doi.org/10.15388/BJPS.2013.2.2818

Pedi, R. (2016), Theory of International Relations: Small States in the International System, PhD thesis, Thessaloniki: University of Macedonia. School of Social Sciences, Humanities and Arts, Department of International Relations. Retrieved from http://thesis.ekt.gr/thesisBookReader/id/38599\#page/1/mode/2up [accessed Feb 2019]

Pedi, R. \& Kouskouvelis, I. (2019), 'Cyprus in the Eastern Mediterranean: a small state seeking for status,' in S. Litsas \& A. Tziampiris (eds.) The New Eastern Mediterranean, New York: Springer, pp. 151-167.

https://doi.org/10.1007/978-3-319-90758-1_9

Petridou, E.; Aflaki, I. \& Miles, L. (2015), 'Unpacking the theoretical boxes of political entrepreneurship,' in I. Aflaki, E. Petridou \& L. Miles (eds.) Entrepreneurship in the Polis: Understanding Political Entrepreneurship, London: Ashgate Publishing, Ltd., pp. 1-16.

Platias, A. (1986), High Politics in Small Countries: An Inquiry into the Security Policies of Greece, Israel and Sweden, $\mathrm{PhD}$ thesis, Ithaca: Cornell University. 
Posner, R. A. (2009), The Problematics of Moral and Legal Theory, Boston: Harvard University Press.

Pozen, D. (2008), 'We are all entrepreneurs now,' Wake Forest Law Review, vol. 43, pp. $283-340$.

Prasad, N. (2009), 'Small but smart: Small states in the global system,' in A. Cooper \& T. Shaw (eds.) The Diplomacies of Small States: Between Resilience and Vulnerability, New York: Palgrave MacMillan, pp. 41-64. https://doi. org/10.1057/9780230246911_3

Prause, G. (2014), 'Smart specialization and EU eastern innovation cooperation: a conceptual approach,' Baltic Journal of European Studies, vol. 4, no. 1, pp. 3-19. https://doi.org/10.2478/bjes-2014-0001

Rickli, J. M. (2008), 'European small states' military policies after the cold war: from territorial to niche strategies,' Cambridge Review of International Affairs, vol. 21, no. 3, pp. 307-325. https://doi.org/10.1080/09557570802253435

Ripsman, N. M.; Taliaferro, J. W. \& Lobell, S. E. (2016), Neoclassical Realist Theory of International Politics, Oxford: Oxford University Press. https://doi.org/10.1093/acprof:oso/9780199899234.001.0001

Sarasvathy, S. D. \& Venkataraman, S. (2011), 'Entrepreneurship as method: open questions for an entrepreneurial future,' Entrepreneurship Theory and Practice, vol. 35, no. 1, pp. 113-135. https://doi.org/10.1111/j.1540-6520.2010.00425.x

Sarri, K. et al. (2012), 'Introduction to entrepreneurship,' [in Greek] in K. Sarri \& A. Trihopoulou (eds.) Women Entrepreneurship, An Approach to the Greek Reality, Athens: Rosili, pp. 20-39.

Schmidl, E. (2001), 'Small states and international operations,' in E. Reiter \& H. Gartner (eds.) Small States and Alliances, Heidelberg: Physica Verlag, pp. 85-89. https://doi.org/10.1007/978-3-662-13000-1_8

Smed, U. T. \& Wivel, A. (2017), 'Vulnerability without capabilities? Small state strategy and the international counter-piracy agenda,' European Security, vol. 26, no. 1, pp. 79-98. https://doi.org/10.1080/09662839.2016.1265941

Solarte-Vásquez, M.C. \& Nyman-Metcalf, K. (2017), 'Smart contracting: a multidisciplinary and proactive approach for the EU digital single market,' Baltic Journal of European Studies, vol. 7, no. 2, pp. 208-246. https://doi.org/10.1515/bjes-2017-0017

Súilleabháin, A. Ó. (2014), Small States at the United Nations: Diverse Perspectives, Shared Opportunities, New York: International Peace Institute.

Tarp, M. N. \& Hansen, J. O. B. (2013), Size and Influence: How Small States Influence Policy Making in Multilateral Arenas, DIIS Working paper, no. 2013: 11, Copenhagen: Danish Institute for International Studies.

The World Bank (2018), Small but Smart: Benin and Togo Cooperate to Ensure Water Security. Retrieved from https://www.worldbank.org/en/news/feature/2018/01/25/ 
small-but-smart-benin-and-togo-cooperate-to-ensure-water-security [accessed 6 Nov 2018]

Thorhallsson, B. (2012), 'Small states in the UN security council: means of influence?' The Hague Journal of Diplomacy, vol. 7, pp. 135-160. https://doi.org/10.1163/187119112X628454

Tiilikainen, T. (2006), 'Finland - an EU member with a small state identity,' Journal of European Integration, vol. 28, no. 1, pp. 73-87. https://doi.org/10.1080/07036330500480599

Waltz, K. (1979), Theory of International Relations, Reading: Addison-Wesley.

Wivel, A. (2010), 'From small states to smart state: devising a strategy for influence in the European Union,' in R. Steinmetz \& A. Wivel (eds.) Small States in Europe: Challenges and Opportunities, Abingdon: Ashgate, pp. 15-30. 